\title{
Dampak Higgs Domino Island dalam Masyarakat (Kajian Dengan Perspektif Sosiologi Hukum)
}

\author{
Nasruddin Khalil Harahap* \\ IAIN Padangsidimpuan \\ Email: nasruddinhrp@iain-padangsidimpuan.ac.id
}

\begin{abstract}
The era of the Industrial Revolution 4.0 has an impact on overall changes in various sectors. Its development has made every country, both developed and developing countries, to improve and renew each other in their respective countries. The development of technology, so can have both positive and negative impacts. One of the developments is the increasing number of online games, both for transactions and non-transactions. The online game that will be studied is the Higgs Domino Island online game. Users or players can make chip/money transactions belonging to other users or players. This research is a field research using the interview method on users/players of the Higgs Domino Island Online. The hope from this research is that the public understands which games are allowed and which are prohibited in the applicable laws and regulations and the government must limit the games that can be used by every citizen by making regulations.
\end{abstract}

Keyword: Online games, Restrictions, and Transactions

\begin{abstract}
Abstrak
Era Revolusi Industri 4.0 berdampak pada perubahan secara menyeluruh di berbagai sektor. Perkembangannya membuat setiap negara negara baik negara maju begitu pula dengan negara berkembang untuk saling berbenah dan memperbaharui negaranya masing masing. Dengan semakin majunya teknologi ini, maka akan dapat berdampak positif maupun negatif. Salah satu perkembangannya adalah semakin maraknya permainan online (game online) baik yang dapat dilakukan dalam bentuk bertransaksi maupun yang bentuk non transaksi. Game online yang akan menjadi kajiannya adalah game online Higgs Domino Island. Pengguna atau pemain game tersebut dapat melakukan transaksi chip/uang yang dimiliki kepada pengguna atau pemain lain. Penelitian ini merupakan penelitian lapangan (field research) dengan menggunakan metode wawancara pada pengguna Aplikasi Game Online Higgs Domino Island. Harapan dari penelitian ini agar masyarakat dapat memahami permainan yang diperbolehkan dan permainan mana yang dilarang dalam peraturan perundang-undangan yang berlaku dan Pemerintah
\end{abstract}


harus membatasi game yang dapat dipergunakan oleh setiap warga negara dengan membuat regulasi.

Kata kunci :Game online, pembatasan, transaksi

\section{PENDAHULUAN}

Perkembangan zaman modern dewasa ini, permainanan game online tidak asing dalam pesatnya perkembangan teknonolgi, dimana hampir semua lapisan masyarakat menggunakan dan memakai game online. Beberapa tahun terakhir, permainan elektronik yang sering disebut dengan game online sudah menjamur dimana-mana. Gadget/Smartphone yang semakin canggih dan computer dengan menggunakan atau memakai internet sangat membantu masyarakat di Indonesia dalam mencari informasi yang diperlukan atau dibutuhkannya, baik dalam sektor pendidikan, kesehatan, ekonomi, politik, hukum dan lainnya. Namun, masyarakat di Indonesia memakai jasa internet untuk bermain game online dikarenakan sangat banyak provider game menawarkan aplikasi game berupa game offline maupun yang online (Jasmadi, 2004).

Keberadaan Game Online memberikan nuansa baru khususnya dalam gadged/smartphone, dikarenakan terdapat interaksi sosial dengan orang lain secara intensif dan seru dikarenakan game online dapat dilakukan bersama sama dengan teman sehingga timbul rasa keasikan dalam bermain game dan menggunakannya dalam waktu lama (Rajagukguk \& Sofianto, 2020; Tohet \& Mauliza, 2021). Sejalan dengan perkembangan dan kemajuan teknologi internet, maka berdampak pula semakin maraknya game online yang dapat di download dan digunakan oleh seluruh masyarakat. Adapun game online yang sering digunakan oleh penggunanya ialah seperti Mobile Lagend, Higgs Domino Island, Free Fire, PUBG dan lain Sebagainya.

Pada masa sebelum maraknya game online di internet, anak-anak sangat aktif bermain secara berkelompok sehingga terjalin interaksi sosial dan kekompakan diantara para anak tersebut. Permainan yang sering dimainkan seperti gasing, layangan, bola kasti, petak umpet dan lainnya. Permainan permainan tersebut tidak dapat dimainkan seorang diri melainkan harus dimainkan dengan kelompok sehingga anak anak sejak kecil telah terbiasa melakukan hubungan sosial dan menjalin kebersamaan dan kekompakan di antara anak dengan anak yang lainnya. Namun pada saat ini, permainan secara tradisional tersebut seiring perkembangan teknologi secara perlahan dilupakan dan ditinggalkan. Anak-anak lebih memilih permainan instant/praktis dan lebih 
mudah untuk dimainkan, dikarenakan cukup dengan men-download games sudah dapat memainkan game tersebut. adapun yang mendasari orang Indonesia tertarik dan sering bermain game online ialah pesatnya infrastuktur dan fasilitas internet diseluruh daerah baik daerah perkotaan maupun daerah pedesaan yang memudahkan pengguna dalam mengakses dan menggunakan game online. Kemudian persaingan antar pelaku usaha pemilik game dalam membuat game yang menarik untuk dapat digunakan oleh konsumennya, dengan demikian maka muncullah berbagai macam pillihan aplikasi yang dapat di gunakan oleh konsumen.

Menurut Perspektif Islam terkait Game Online, asal hukum dari game online di computer atau handphone adalah boleh (Amin, 2021). Islam mengakui fitrah dan pemikiran manusia sebagai makhluk yang di ciptakan Allah dengan suka bergembira, bersenang-senang, ketawa dan bermain-main, sebagaimana di ciptakan mereka suka makan dan minum (Qardhawi, 1993). Manusia untuk memperoleh kebahagiaan dan kegembiraannya dapat melakukannya dengan cara olahraga, menyanyi, bermain game, dan lain sebagainya. Pada hakikatnya Islam sendiri tidak melarang permainan sepanjang permainan tersebut tdak melanggar norma/aturan syariat (hukum Islam), seperti dapat mengakibatkan bahaya, terdapat unsur tipu muslihat untuk orang lain, menyakiti binatang, permainan yang terdapat unsur keberuntungan dan mengandung unsur perjudian (Qardhawi, 2005). Sebab salah satu karakter judi ialah mengandung untung-rugi

Maysir atau judi merupakan tindak pidana yang berdampak negatif, dengan mengakibatkan rusaknya ekonomi keluarga, mengganggu keamanan atau ketertiban masyarakat, melumpuhkan semangat kreasi, dan menyiakan waktu (Z. Ali, 2009). Perjudian sudah sangat sukar dihilangkan atau dimusnahkan, bahkan kemajuan dari teknologi informasi menjadi salah satu unsur dalam memberikan konstribusi atau menambah menjamurnya perjudian, salah satunya yakni dengan menggunakan aplikasi permainan Higgs Domino Island. Perjudian tidak hanya di kota, masyarakat di desa pun saat ini banyak yang bermain judi. Masyarakat yang bermain judi sudah hampir seluruh kalangan, baik muda dan tua sudah menjadi satu hal umum dalam bermain judi. Pada Umumnya, Prinsip dalam berjudi bertujuan untuk memperoleh keuntungan yang sangat besar. Keuntungan yang diperoleh akan sesuai dengan taruhan yang dibuat, semakin banyak uang taruhan maka keuntungan akan jauh lebih besar. 
Menurut Adams dan Rollings, game online adalah permainan yang dapat diakses oleh banyak pemain yang dihubungkan oleh jaringan internet. Game online mempunyai daya tarik dan sudah menjadi rutinitas setiap hari. Selain permainan yang menarik, game online juga dapat menyebabkan ketagihan karena ketika sedang bermain kemudian kalah akan mencoba kembali supaya menang. Game online memiliki dampak positif tidak hanya meningkatkan keterampilan fisik namun juga kemampuan intelektual dan fantasi pada pengguna, sementara sisi negatifnya yaitu terbengkalinya kegiatan atau pekerjaan rumah, menggunakan waktu luang untuk bermain game dan kurang hubungan atau interaksi sosial dengan orang sekitar (Nisrinafatin, 2020).

Higgs Domino Island merupakan game online yang bisa di download di playstore dengan jenis permainan yang sangat banyak seperti Domino, Kartu, dan Slot. Game online dapat diakses dan dimainkan bila sudah terhubung dengan jaringan internet. Pemain bisa mendapatkan pulsa dan chip (koin) dapat diperjual belikan dengan meng-upgrade akun Perunggu. Setelah menjadi Akun Perunggu, maka pemain hanya boleh melakukan/mengirim chip/koin sebanyak 2 Billion Chip. Pemain bisa melakukan TopUp sebesar Rp.10.000 (sepuluh ribu rupiah) yang bisa dilakukan menggunakan pulsa (penyedia jaringan seperti Telkomsel, Indosat, 3) atau pemain bisa juga dengan Dompet Digital Gopay. Setelah melakukan Top-Up, maka pemain mendapatkan 120.000.000 (seratus dua puluh juta) chip dan 30.000.000 (tiga puluh juta) chip, yang dapat dipakai pemain untuk bermain disetiap jenis permainan yang tersedia di aplikasi Higgs Domino (Ramadhani, 2021).

Para pemain lebih sering membeli chip dari pemain lainnya dikarenakan harganya akan lebih murah dibanding jika pemain membeli melalui Aplikasi/mitra aplikasi www.topbos.com. Harga 1 Billion bila dibeli dari pemain dikisaran Rp.55.000 - Rp.65.000, sementara pada Mitra Aplikasi di harga Rp.70.000. kemajuan teknologi komunikasi, memudahkan orang untuk melakukan transaksi tanpa berjumpa untuk melakukan transaksi jual beli. Dengan memanfaatkan media, tidak hanya dapat menjual chip secara langsung kepada pembeli, pemain (penjual) yang mempunyai chip dapat menjualnya juga di online shop semisal Shopee, Tokopedia, Bukalapak. 


\section{METODE PENELITIAN}

Penelitian ini menggunakan metode pendekatan yuridis normatif, dilakukan terhadap norma-norma yang terwujud dalam peraturan perundang-undangan yang berkaitan, diantaranya KUHPidana, Undang-undang Perlindungan Konsumen, UU ITE dengan didukung informasi-informasi yang diperoleh dari buku literatur, surat kabar dan media online, maupun hasil karya para sarjana yang berkaitan dengan penelitian ini. Spesifikasi Penelitian yang digunakan dalam penelitian ini adalah deskriptif analitis. Tahap penelitiaan yang dilakukan dalam lingkup penelitian ini adalah studi kepustakaan dan studi lapangan.

Penelitian terhadap data sekunder berupa bahan-bahan hukum yang terdiri dari bahan hukum primer, bahan hukum sekunder adalah buku literatur, ajaran para ahli, hasil karya ilmiah para ahli, berita-berita dari media online yang berkaitan dengan dampak Higgs Domino Island dalam masyarakat, dan bahan hukum tersier serta penelitian lapangan. Penulis melakukan wawancara. Teknik pengambilan sampel yang digunakan adalah menggunakan rancangan sampel non-probabilitas (nonprobability sampling design), (Harahap, 2021) yang berbentuk Incidental Sampling. Incidental Sampling ialah metode menentukan sampelnya dengan cara atau mekanisme kebetulan, yaitu pemain atau pengguna aplikasi higgs domino island yang secara kebetulan/insidental berjumpa dengan peneliti di lapangan yang dapat digunakan sebagai sampel (Sugiyono, 2013).

\section{Hasil dan Pembahasan}

Game Online merupakan cara gaya hidup beberapa orang disetiap kalangan, termasuk anak muda ataupun pelajar. Zaman sekarang, banyak dijumpai warung internet (warnet) dikota ataupun di desa-desa dan mereka memfasilitasi akan adanya game online tersebut. Berbagai macam jenis game online dimulai dari genre perang, strategi, balapan, olahraga dll. Game dapat dimainkan dengan aturan tertentu sehingga ada yang menang dan ada yang kalah, biasanya dalam konteks tidak serius atau keadaan refreshing ((Surbakti, 2017). Penggunaan game online menimbulkan dampak positif dan dampak negative bagi pemainnya, yakni :

1. Dampak Positif

a. Game online membuat pintar: Seorang pemain game online yang bermain min $28 \mathrm{jam} / \mathrm{minggu}$ atau rata rata 4 jam/hari memiliki koordinasi yang baik antara kecepatan tangan dengan repleksi mata yang memadai. 
b. Meningkatkan konsentrasi: Pemain memiliki konsentrasi yang tinggi, dikarenakan para pemain dapat focus dalam menyelesaikan dan menuntaskan tantangan tantangan dalam game.

c. Memiliki ketajaman mata yang lebih cepat: Dengan bermain game, maka ketajaman mata akan jauh lebih cepat dibanding yang tidak pernah bermain game.

2. Dampak Negatif

a. Masalah psikologi: Penggunaan game online yang berlebihan akan mengakibatkan perilaku yang anti sosial, penurunan interaksi sosial, dan penurunan empati terhadap apa yang terjadi di lingkungan sekitar.

b. Menyebabkan masalah kulit: Kelebihan dalam menggunakan game online akan mengakibatkan masalah kulit, seperti kekakuan, tangan Chaffed, dan gangguan kulit yang disebabkan oleh konsol game.

c. Mempengaruhi kecerdasan Emosional: Mengakibatkan meningkatnya tingkat emosi dan sikap temperamental dikarenakan mengalami kekalahan dalam bermain game.

Adapun upaya untuk mengatasi kebiasaan bermain game online adalah sebagai berikut:

1. Bersungguh-sungguh (niat).

2. Mempunyai pikiran hemat.

3. Mencari aktivitas lain.

4. Membatasi waktu bermain game online.

Game Online memiliki beberapa jenis, baik itu yang sederahana sampai yang memiliki grafik yang sangat kompleks. Ada pun beberapa jenis (genre) Game Online yaitu :

1. Massively Multiplayer Online First-person shooter Games (MMOFPS) merupakan

Game Online yang mengambil sudut pandang orang pertama sehingga seolah-olah pemain berada dalam permainan tersebut dalam sudut pandang tokoh karakter yang dimainkan, dimana setiap tokoh memiliki kemampuan yang berbeda dalam tingkat akurasi, refleks, dan lainnya. Contohnya antara lain Counter Strike, Call of Duty, Point Blank, Quake, Blood, Unreal.

2. Massively Multiplayer Online Role-playing Games (MMORPG) merupakan Game yang biasanya memainkan peran tokoh-tokoh khayalan dan berkolaborasi untuk merajut sebuah cerita bersama. RPG biasanya lebih mengarah ke 
kolaborasi sosial daripada kompetisi. Contohnya seperti Ragnarok Online ,The Lord of the Rings Online: Shadows of Angmar, Final Fantasy, Dota 2, Mobile Legend

3. Simulation Games merupakan jenis game yang bertujuan untuk memberi pengalaman melalui simulasi. Pada life-simulation Games, pemain bertanggung jawab atas sebuah tokoh atau karakter dan memenuhi kebutuhan tokoh selayaknya kehidupan nyata, namun dalam ranah virtual. Sebagainya. diantaranya life-simulation Games, construction and management simulation Games, dan vehicle simulation.

4. Massively multiplayer Online Games (MMOG). Pemain bermain dalam dunia yang skalanya besar, dimana setiap pemain dapat berinteraksi langsung seperti halnya dunia nyata. MMOG muncul seiring dengan perkembangan akses internet broadband di negara maju, sehingga memungkinkan ratusan, bahkan ribuan pemain untuk bermain bersama-sama. Misalnya PUBG, Higgs Domino Island.

Banyaknya jenis dari game online, maka Islam pun memberikan batasan batasan terkait game apa saja yang diperbolehkan dan game yang tidak diperbolehkan. Adapun permainan yang diperbolehkan oleh Nabi atau para Sahabat yaitu sebagai berikut :

1. Perrmainan memanah: Rasulullah pernah lewat kepada kelompoknya yang sedang berlatih memanah, dan memberikan motivasi dan semangat kepada mereka dengan berkata :

"Memanahlah dan aku bersama kalian Semua"

Beliau memperingatkan agar tidak menjadikan binatang ternak menjadi sasaran panah sebagai latihan, sebagai mana hal tersebut telah terjadi sebelumnya. Dengan demikian, bahwa Islam memerintahkan dan menyuruh kita untuk menyayangi binatang, melarang menyiksa dan berbuat jahat kepada binatang ternak.

2. Permainan menunggang kuda

Rasulullah bersabda :

"Segala sesuatu yang didalamnya tidak ada dzikir (mengingat Allah), maka ia adalah permainan yang melalaikan, kecuali empat macam yaitu : memanah, melatih kudanya, bercumbu dengan istrinya, dan belajar berenang."

3. Permainan lari marathon 
Para sahabat berrlomba lari sesama mereka, dan Nabi menyetujui permainan lomba lari tersebut. bahkan Rasulullah pernah berlomba lari dengan Istrinya 'Aisyah sebagai hiburan dan pelajaran bagi para sahabat, dengan bersabda:

"Rasulullah mengejarku, maka aku kejar beliau. Saya terus unggul dalam setiap kali berlomba. Namun ketika badanku jadi gemuk, lantas kami berlomba lari lalu beliau dapat mengungguli, maka beliau berkata satu - satu."

Selain permainan yang diperbolehkan, islam pun melarang sebagaian dari jenis pernainan yang ada karena dianggap bertentangan dengan tujuannya dan menyimpang dari segi tata caranya. Adapun permainan yang dilarang dalam Islam, yakni sebagai berikut :

1. Bermain dadu: Permainan dadu berdasarkan Jumhur Ulama sepakat bahwa apabila permainan dadu disertai dengan uang yang diambil oleh pemenang dan dibayarkan oleh yang kalah termasuk dalam kategori Haram dan termasuk Judi (qimar). Permainan dadu yang sampai melalaikan dari melaksanakan kewajibannya, misal shalat maupun lalai terhadap keluarga (anak dan Istri). Misalnya permainan Ular tangga, Monopoli dan kartu domino.

2. Bermain catur: Para Ulama sepakat bahwa permainan catur yang disertai taruhan baik berupa materiil maupun immaterial hukumnya adalah haram. Apabila melalaikan dalam melaksanakan kewajibannya seperti sholat juga dikatakan haram. Kemudian jumhur Ulama menyebutkan apabila pemenang mendapatkan hadiah dari panitia penyelenggara juga termasuk hukumnya haram, dikarenakan dtidak mengandung makna ketangkasan jihad.

3. Bermain judi dan taruhan: Judi artinya taruhan, baik dengan mata uang maupun benda. Dengan kata lain, bahwa judi merupakan suatu tindakan untuk mencari keuntungan yang dilakukan maupun dilaksanakan dengan cara atau metode untung-untungan, yaitu cara menerka dan mensyaratkan pembayaran terlebih dahulu. Apabila terkaan benar, maka dia akan beruntung. Namun apabila terkaannya salah maka orang tersebut akan rugi.

Berdasarkan hal tersebut di atas, sangat jelas bahwa Islam memberikan batasan batasan terkait dengan game mana yang diperbolehkan untuk dimainkan dan game mana pula yang tidak diperbolehkan. Sementara dalam hukum positif (peraturan perundang-undangan yang berlaku) belum mengatur lebih jelas terkait permainan yang diperbolehkan, akan tetapi apabila kegiatan 
tersebut judi dan merugikan pihak lain maka akan termasuk dalam tindak pidana.

Pada penelitian ini, peneliti melakukan penyebaran quisioner kepada 40 orang responden/ pemain yang bermain Higgs Domino Islan. 40 responden mengisi quisioner dan 5 responden diantaranya digunakan pula metode wawancara. Keseluruhan responden berdomisili di Padangsidimpuan, dan berasal dari daerah Tapanuli bagian Selatan (Tapanuli Selatan, Mandailing Natal, Padangsidimpuan, Padanglawas Utara, dan Padanglawas). Maka berdasarkan quisioner yang diisi diperoleh hasil datanya sebagai berikut:

a. Usia Responden

\begin{tabular}{llll}
\hline \hline No & Jarak Umur & Responden & Percent \\
\hline \hline 1 & 15-20 Tahun & 10 & $25,0 \%$ \\
\hline 2 & $21-25$ Tahun & 15 & $37,5 \%$ \\
\hline 3 & $26-30$ Tahun & 8 & $20,0 \%$ \\
\hline 4 & 31-40 Tahun & 5 & $12,5 \%$ \\
\hline 5 & Di atas 40 tahun & 2 & $5,0 \%$ \\
\hline \hline
\end{tabular}

b. Pekerjaan Responden

\begin{tabular}{llll}
\hline \hline No & Pekerjaan & Responden & Percent \\
\hline \hline 1 & Pelajar & 8 & $20,0 \%$ \\
\hline 2 & Mahasiswa & 15 & $37,5 \%$ \\
\hline 3 & Wiraswasta & 10 & $25,0 \%$ \\
\hline 4 & ASN & 7 & $17,5 \%$ \\
\hline \hline
\end{tabular}

c. Asal Responden

\begin{tabular}{llll}
\hline \hline No & Jarak Umur & Responden & Percent \\
\hline \hline 1 & Tapanuli Selatan & 8 & $20,0 \%$ \\
\hline 2 & Mandailing Natal & 7 & $17,5 \%$ \\
\hline 3 & Padangsidimpuan & 15 & $37,5 \%$ \\
\hline 4 & Padanglawas Utara & 5 & $12,5 \%$ \\
\hline 5 & Padang lawas & 5 & $12,5 \%$ \\
\hline \hline
\end{tabular}

d. Kuota Internet yang di gunakan per bulan

No Jumlah Kuota Responden Percent




\begin{tabular}{llll}
\hline \hline 1 & $2 \mathrm{~Gb}-5 \mathrm{~Gb}$ & 5 & $12,5 \%$ \\
\hline 2 & $5 \mathrm{~Gb}-10 \mathrm{~Gb}$ & 10 & $25,0 \%$ \\
\hline 3 & $10 \mathrm{~Gb}-20 \mathrm{~Gb}$ & 10 & $25,0 \%$ \\
\hline 4 & $20 \mathrm{~Gb}-40 \mathrm{~Gb}$ & 5 & $12,5 \%$ \\
\hline 5 & Unlimited/Wifi & 10 & $25,0 \%$ \\
\hline \hline
\end{tabular}

e. Jenis permainan yang digunakan

\begin{tabular}{llll}
\hline \hline No & Jenis Permainan & Responden & Percent \\
\hline \hline 1 & PUBG & 8 & $20 \%$ \\
\hline 2 & Higgs Domino & 24 & $60 \%$ \\
\hline 3 & Mobile Legend & 8 & $20 \%$ \\
\hline 4 & Football game & - & - \\
\hline \hline
\end{tabular}

f. Intensitas bermain game Higgs Domino Island per minggu

\begin{tabular}{llll}
\hline \hline No & Jumlah main & Responden & Percent \\
\hline \hline 1 & Sekali & 5 & $12,5 \%$ \\
\hline 2 & Dua kali & 5 & $12,5 \%$ \\
\hline 3 & Tiga kali & 10 & $25,0 \%$ \\
\hline 5 & Tiap Hari & 20 & $50,0 \%$ \\
\hline \hline
\end{tabular}

g. Intensitas melakukan transaksi per bulan

\begin{tabular}{llll}
\hline \hline No & Jarak Umur & Responden & Percent \\
\hline 1 & $1-3$ kali & 15 & $37,5 \%$ \\
\hline 2 & $4-6$ kali & 10 & $25,0 \%$ \\
\hline 3 & $7-10$ kali & 10 & $25,0 \%$ \\
\hline \hline & Lebih dari 10 kali & 5 & $12,5 \%$ \\
\hline
\end{tabular}
menggunakan permainan Higgs Domino Island, dari total 40 Orang responden terdapat 24 responden dengan persentasi sebanyak 60\% dibandingkan dengan game lainnya. Hal ini dikarenakan game online Higgs Domino Island dapat menambah income atau sumber tambahan keuangan bagi konsumen disebabkan mudahnya untuk melakukan transaksi chip/koin antar pemain game online tersebut. Berikut adalah uraian dari tabel, yaitu: 
Berdasarkan usia pengguna game online Higgs Domino Island, terdapat 25 orang dengan $62,5 \%$, penggunanya masih berusia antara 15 tahun sampai dengan 25 tahun. Kemudian terdapat 13 orang dengan 42,5\% yang interval usianya 26 tahun sampai dengan 40 tahun, serta terdapat 2 orang dengan $5 \%$ yang interval usianya di atas 40 tahun. Terkait hal pekerjaan, terdapat 8 orang dengan $20 \%$ pengguna masih berstatus pelajar, 15 orang dengan 37,\% masih mahasiswa, 10 orang dengan 25,0\% pengguna berprofesi wiraswasta, dan 7 orang dengan 17,5\% berprofesi ASN. Dalam hal pemakaian kuota Internet, terdapat 15 orang dengan 37,5\% menggunakan kuota internet sekitar 2-10Gb, 15 orang dengan 37,5\% menggunakan kuota sekitar 20-40Gb, dan 10 orang dengan 25,0\% menggunakan internet $\mathrm{WiFi}$.

Dilihat dari jenis permainan atau game online yang digunakan oleh responden, dapat ditarik kesimpulan bahwa 8 orang dengan $20 \%$ menggunakan game online PUBG, 24 orang dengan 60\% menggunakan game online Higgs Domino Island, dan 8 orang dengan 20\% menggunakan game online Mobile Legend. Dengan kata lain bahwa saat ini, game online yang sering digunakan atau dipakai oleh para responden adalah Higgs Domino Island karena game online tersebut mudah untuk dimainkan dan dapat menghasilkan pundi pundi uang. Apabila dilihat dari segi intensitas penggunaan game online Higgs Domino Island ini, yaitu 20 orang dengan 50\% menggunakan game online tersebut sebanyak 1 sampai dengan 3 kali dalam seminggu, 20 orang dengan 50 $\%$ menggunakan game onlinenya setiap hari dengan tujuan untuk mengumpulkan lebih banyak jumlah chip/koin. Jika dilihat dari segi intensitas melakukan transaksi penjualan chip/koin terdapat 25 orang dengan 62,5\% yang melakukan transaksi interval 1 sampai dengan 6 kali transaksi dalam sebulan, dan 15 orang dengan 37,5\% pengguna game online Higgs Domino Island melakukan transaksi kepada pemain lain dengan interval intensitas transaksi di atas 7 kali transaksi dalam sebulan

Ridho Hasibuan selaku pelajar menyatakan bahwa game online Higgs Domino Island pertama kali diketahuinya dari teman sekolahnya yang sudah terlebih dahulu menggunakannya. Setelah mendownload dan menggunakannya, responden merasa bahwa game online tersebut dapat membantu biaya kehidupannya dikarenakan dengan menggunakan dan menjual chip/koin secukupnya dapat memenuhi kebutuhan sehari-hari. Responden biasanya bermain game ini tiga kali dalam seminggu, dalam sebulan melakukan transaksi 
kisaran 5-7 B chip/koin dengan kisaran uang Rp.350.000 - Rp.500.000 (Wawancara dengan Ridho Hasibuan, pada tanggal 01 November 2021). Beda halnya dengan Agus Sidabutar selaku wiraswasta menyatakan bahwa responden menggunakan Higgs Domino Island hampir setahun dengan tiap hari bermain unutk mengumpulkan chip/koin. Responden dalam sebulan menjual/ transaksi chip/koin kisaran 15-20 B, jumlah uang yang diperoleh kisaran Rp. 975.000 hingga Rp.1.300.000. Hal ini membuat responden jadi malas untuk bekerja dan lebih fokus dalam bermain game ini, karena dengan bermain game online seharian maka akan dapat membuka peluang untuk menambah chip/koin yang nantinya akan dijual kembali kepada pemain lain (Wawancara dengan Agus Sidabutar, pada tanggal 03 November 2021).

Menurut Sam Nasution selaku ASN menyebutkan bahwa Higgs Domino Island merupakan game online yang cendrung ke arah perjudian,sehingga hukumnya bisa dikatakan haram. Hal ini dikarenakan adanya transaksi jual beli yang dilakukan oleh antar pemain dan tidak adanya ketentuan yang jelas terkait penentuan harga jual beli dari chip/koin oleh pembuat atau pemilik dari game online tersebut. Menurut Responden, game online ini akan menjadi permasalahan serius apabila sudah marak digunakan oleh para pelajar di tingkat SD maupun SMP. Oleh karenanya perlu pembatasan dan pengawasan dari Pemerintah, pihak Sekolah atau Kampus, maupun dari pihak Keluarga dan Lingkungan domisili pengguna. Pemerintah seharusnya membatasi usia yang diperkenankan untuk menggunakan game Higgs Domino Island, sebagaimana halnya pemerintah membuat batasan batasan umur untuk aplikasi yang tidak diperkenankan dikonsumsi oleh anak di bawah umur (Wawancara dengan Sam Nasution, pada tanggal 08 November 2021). Pemerintah juga dapat memblokir atau menghapus aplikasi Higgs Domino Island di Playstore, sehingga tidak akan berdampak luas dalam kehidupan bermasyarakat.

Fenomena permainan Higgs Domino Island ini tidak hanya terjadi di daerah Tapanuli Bagian Selatan saja, namun sudah marak hampir di seluruh wilayah Indonesia. Berikut adalah beberapa contoh permasalahan hukum yang timbul di beberapa daerah :

1. Rokan Hulu, Riau: Polres Rokan Hulu melakukan penangkapan kepada agen Higgs Domino Island, dengan dugaan telah melakukan tindak pidana perjudian online jenis Higgs Domino. Pelaku mengatakan bahwa dirinya telah menjadi agen/ penjual chip game online tesebut selama 2 bulan terakhir, 
pelaku ditangkap dengan barang bukti berupa uang tunai Rp.630.000 setelah sukses menjual chip kepada konsumen sebanyak 9 B dengan kisaran harga Rp.70.000. Pelaku dikenakan Pasal 303 KHUPidana Tentang Perjudian dengan ancaman paling lama 10 Tahun atau denda paling banyak Rp.25.000.000 (Bintang, 2021).

2. Pidie, Aceh: 10 orang pelanggar berdasarkan putusan mahkamah syar'iyah telah melanggar ketentuan Qanun Pasal 18 Jo Pasal 20 tentang Hukum Jinayat, dihukum sebanyak 20 kali cambuk. Hukumam tersebut dikurangi menjadi 18 kali cambukan dikarenakan potong tahanan. Sepuluh orang tersebut telah diberikan hukuman cambuk dan disaksikan oleh khalayak umum.

3. Banda Aceh, Aceh: Polresta Banda Aceh menangkap 2 orang yang diduga sebagai agen Higgs Domino Island. Pada saat penangkapan, terdapat barang bukti berupa chip/koin berisi 87 B (kisaran lebih dari Rp.5 juta) dan uang tunai Rp.200.000. Kemudian menangkap 2 orang lagi dengan mengamankan barang bukti berupa 4 unit ponsel dan uang sebesar Rp.1,4 juta. Keempat orang tersebut, 3 orang diantaranya adalah agen dan 1 orang adalah pembeli. Para pelaku ini dijerat dengan Pasal 18 Jo Pasal 20 Qanun Provinsi Aceh No. 6/2014 Tentang Hukum Jinayat (W, 2021)

Berdasarkan hal tersebut di atas sangat jelas bahwa game online Higgs Domino Island merupakan game yang mengandung maysir di dalam nya dan tidak sesuai dengan ketentuan peraturan perundang-undangan yang berlaku maupun dengan syariat Islam. MUI dan Ormas ormas diberbagai daerah juga telah mengeluarkan fatwa tentang penggunaan game online Higgs Domino Island. Para Ulama tersebut sepakat bahwa hukum dari Higgs Domino Island ini ialah haram. Berikut ini fatwa fatwa yang dikeluarkan oleh MUI dan Ormas ormas Islam di beberapa daerah, seperti MUI Sulsel yang menyebutkan game online Higgs Domino Island memiliki unsur perjudian di dalamnya karena ada unsur mengadu keberuntungan, ada pembelian chips/koin , adanya perputaran uang. Dalam memainkan game online ini, pengguna harus memiliki chip/koin dan banyak pengguna yang menghalalkan segala cara untuk mendapatkan dan membeli chip. MUI Sulsel menyatakan bahwa permainan game online hanya peralihan media dari offline ke online dalam bentuk game online, dan terdapat 
unsur untung rugi didalamnya. Hal inilah yang mendasari MUI Sulsel menyatakan game online Higgs Domino Islan ini hukumnya termasuk haram.

PWNU Aceh juga mengharamkan judi game online Higgs Domino Island dikarenakan adanya praktek perjudian dalam permainan tersebut. Pada putusan tersebut tidak hanya mengharamkan game online yang mengandung judi, namun game online yang tidak mengandung unsur judi bisa dikategorikan haram apabila game tersebut menimbulkann kemudharatan (segi buruk) baik pada fisik maupun pada mental para pemainnya. PWNU juga merekomendasikan agar pemerintah memblokir semua situs situs perjudian daring dan game online yang mengandung kriteria perjudian. Ulama Aceh juga meminta agar setiap orangtua memberikan perhatian dan melakukan pengawasan yang serius kepada anak-anaknya sehingga terhindar dari penggunaan game daring.

MUI Sulawesi Tenggara (Sultra) juga mengeluarkan fatwa bahwa game online Higgs Domino Island hukumnya haram karena prinsipnya game online tersebut tidak memberikan kepastian dan sudah memenuhi unsur perjudian. MUI Sultra menegaskan ketika suatu perbuatan dalam bentuk apapun apabila memenuhi unsur judi, maka sudah termasuk haram dan harus ditinggalkan. Apalagi bermain game online sudah menjadi aktivitas rutin yang memberikan dampak buruk seperti malas kerja, keluarga telantar, dan melalaikan ibadah.

PCNU Surabaya, menyampaikan bahwa game online Higgs Domino Island berstatus hukum haram disebabkan mengandung kriteria judi. Ikhwal jual beli chipnya pun demikian dikarenakan para pemain seolah terperdaya lantaran setiap mendapat hoki maka menyebutnya jackpot. Demikian pula halnya saat ingin memberi atau meminta sumbangan chip dengan menyebut istilah info chip. Pada perspektif fiqh dasar bermain game online diperkenankan, namun tidak boleh ada hal hal yang dilarang syariat. Ada 4 hal yang diperbolehkan dalam bermain game online, yaitu:

1. Tidak menyebabkan ghoror pada makhluk hidup

2. Tidak membuat pemainnya berdusta atau melakukan sesuatu yang diharamkan

3. Tidak memalingkan dari kewajiban agama

4. Tidak ada unsur hinaan merendahkan muru'ah pemain.

Pada pemainan game online Higgs Domino Island tidak menggunakan uang asli dalam taruhannya, namun chip/koin yang digunakan dalam permainan itu 
bisa diuangkan dengan cara menjualnya ke pengguna lainnya. Demikian pula halnya dengan MUI Padangsidimpuan yang mengeluarkan fatwa bahwa game online Higgs Domino Island memiliki status hukum haram dikarenakan sudah ada praktek perjudian, adanya untung rugi dan game tersebut melalaikan penggunanya. Hampir semua lapisan masyarakat memainkan game online Higgs Domino Island, dikarenakan terdapat berbagai game seperti domino, kartu, puzle, dam, slot. Slot inilah game yang popular dalam Higgs Domino Island, seperti dofu, docai, rezeki nomplok, fafa, dan 5 dragon. Hal yang menjadi permasalahan ialah ketika Higgs Domino Island adanya taruhan atau terkait jual beli chip dalam memperoleh chip diluar sedekah $2 \mathrm{M}$ dari sistem game online. Harga chip/koin Higgs Domino Island bervariasi yakni mulai dari Rp.55.000 hingga Rp.70.000 per 1B

Berdasarkan hal tersebut di atas bahwa sangat jelas status hukum haramnya game online Higgs Domino Island. MUI dan Ormas ormas diberbagai wilayah Indonesia mengeluarkan fatwa bahwa haramnya game online tersebut. hal ini dikarenakan Higgs Domino Island mengandung maysir /judi (adanya faktor keberuntungan), melalaikan penggunanya, dan membentuk karakter yang buruk (malas, antisocial, dan lainnya).

Pendekatan sosiologis mengenai hubungan hukum dengan moral dan logika internal hukum. focus utama pendekatan sosiologi menurut Gerald Turke antara lain ialah: (A. Ali \& Heryani, 2012)

1. Pengaruh hukum terhadap perilaku sosial.

2. Pada organisasi sosial dan perkembangan sosial serta pranata paranata hukum.

3. Tentang bagaimana hukum dibuat.

4. Tentang kondisi kondisi sosial yang menimbulkan hukum.

Hal hal yang melatar belakangi terhadap pelanggaran dalam kehidupan bermasyarakat ialah sebagai berikut:

1. Tidak adanya sanksi yang cukup berat, masyarakat tidak menghubungkan pelanggaran dengan sanksinya.

2. Pelanggaran yang dilakukan bersama sama, bukan individu.

3. Aturan tidak sesuai dengan kondisi, keadaan, dan keyakinan mereka.

Pendekatan dengan sosiologis menunjukkan bahwa Undang-undang dapat dianalisis terkait dengan bagaimana kenyataannya dan bagaimana pengaruh berlakunya Undang-undang. Kebiasaannya Undang-undang sering dilaksanakan 
tidak sesuai maksud dari pembuat Undang-undang. Ketidak sesuaian pelaksanaan hukum dengan tujuan yang semula pembuat Undang-undang dalam sosiologi hukum disebut goal displacement (pembelokan tujuan) dan goal substitution (penggantian tujuan). Penyelesaian permasalahan dalam tatanan kehidupan bermasyarakat tidak hanya berdasarkan Undang-undang saja melainkan bisa dengan nilai luhurnya. Berbagai kemungkinan peristiwa ketika terdapat perubahan hukum, antara lain: (Fuady, 2007)

1. Hukum berubah seperti keinginan masyarakat

2. Hukum dianggap membawa perubahan besar dalam masyarakat

3. Hukum melakukan pengesahan atau ratifikasi atas peristiwa dalam masyarakat

4. Hukum berubah berdasarkan pendapat pihak lebih kuat dari aspirasi masyarakat

Fenomena penggunaan Higgs Domino Island, dengan maraknya pengguna/pemain yang melakukan jual beli dari chip yang dimiliki menjadi permasalahan hukum baru yang lahir dalam tatanan kehidupan bermasyarakat. Hal tersebut dapat menggerus nilai nilai luhur yang ada dan dilaksanakan dalam masyarakat dikarenakan pengguna atau pemain tidak hanya orang dewasa, melainkan pemain/penggunanya anak-anak dan remaja. Banyaknya hal buruk (mudhorat) dari game online Higgs Domino Islan seperti gamenya mengandung perjudian (transaksi), adanya faktor untung rugi, melalaikan pengguna untuk melakukan kewajibannya. Peristiwa hukum yang terjadi akibat game online ini telah banyak terjadi, misalnya seorang cucu membunuh neneknya demi membeli chip, agen yang mencuri chip, bahkan banyak penipuan yang terjadi pada saat transaksi yang dilakukan oleh antar pengguna/pemain.

Selaras dengan hal tersebut, maka MUI dan Ormas-ormas Islam diberbagai daerah mengeluarkan fatwa haram terkait atas penggunaan game online Higgs Domino Island dikarenakan adanya unsur maysir didalamnya yang dalam Alqur'an dan Al-hadist menyebutkan apabilah ada unsur maysir dalam salah satu hal maka hukumnya haram. Adanya Untung rugi dalam game dan melahirkan sifat lalai dalam menunaikan kewajiban menjadi hal yang pokok pula dalam memutuskan Higgs Domino Island ini termasuk haram. MUI dan Ormas-Ormas Islam mengeluarkan fatwa haram ini dengan tujuan agar masyarakat tidak menggunakannya game online ini lagi, dikarenakan keburukan lebih banyak dibanding dengan keuntungan yang diperoleh. Kemudian menyampaikan pula, 
agar pemerintah membatasi atau memblokir situs situs game online yang memiliki karakteristik perjudian atau maysi. Hal ini sejalan dengan pendapat Gerald Turke, yang menyebutkan kondisi kondisi sosial yang menimbulkan hukum. Karena Higgs Domino Island ini telah digunakan pula oleh anak-anak dikhawatirkan/ditakutkan, secara tidak langsung menanamkan kepada anak anak bermain judi dan membuang waktu sedari usia mudanya. Hal ini akan sangat berdampak buruk di kemudian harinya. Oleh karenanya maka timbullah aturan hukum berupa fatwa haram yang dikeluarkan oleh MUI dan Ormasormas Islam dengan tujuan untuk menjaga nilai nilai luhur baik nilai agama dan nilai nilai adat yang tumbuh dan berkembang di dalam tatanan kehidupan bermasyarakat.

Berdasarkan teori teori perubahan hukum dalam masyarakat, salah satu diantaranya adalah Hukum menyesuaikan diri dengan perubahan masyarakat dimana fungsinya ialah untuk melindungi kepentingan warga masyarakat. Perubahaan hukum senantiasa dimulai dari kesenjangan antara keadilan, peristiwa, dan hubungan dalam masyarakat dengan hukum yang mengaturnya. Oleh karenanya, peranan pemerintah selaku pembuat kebijakan sangat penting dalam hal ini, demi menjaga nilai nilai luhur yang ada dalam kehidupan bermasyarakat maka pemerintah dapat mengambil kebijakan untuk membatasi bahkan memblokir game online yang berkarakteristik perjudian. Pemerintah dapat membentuk regulasi terkait larangan penggunaan game online yang berdampak buruk pada tatanan kehidupan bermasyarakat dan menguatkan kekuatan hukum fatwa haram yang dikeluarkan oleh MUI dan Ormas ormas Islam diberbagai daerah. Oleh karenanya, dengan adanya regulasi tersebut dapat membatasi penggunaan game online, menjaga nilai nilai luhur yang ada dalam masyarakat, dan mencegah agar tidak muncul lagi permasalahan-masalahan hukum baru terkait dari dampak penggunaan Higgs Domino Island.

\section{KESIMPULAN}

Higgs domino Island merupakan game online dengan indeks pengguna tertinggi saat ini. Terjadinya peristiwa jualbeli chip ataupun koin antar sesama pemain, adanya kondisi untung rugi (ketidakpastian), dan membuat pengguna lalai dalam menunaikan maupun menjalankan kewajibannya menjadi dasar pokok bagi MUI dan Ormas Islam. Banyaknya peristiwa hukum yang timbul akibat penggunaan game online ini, seperti penipuan saat proses transaksi antar 
pengguna/pemain bahkan sampai melakukan pembunuhan demi bisa membeli chip menjadi alasan penting perlunya pembatasan penggunaan game online Higgs Domino Island. Urgentnya peranan pemerintah untuk mengeluarkan regulasi terkait pembatasan dan pemblokiran penggunaan aplikasi game online Higgs Domino Island agar tidak timbul lagi peristiwa hukum, dapat menjaga dan melindungi nilai nilai luhur, baik nilai agama maupun nilai nilai adat yang hidup dan berkembang di dalam masyarakat, dan dapat menjaga keharmonisan hidup berdasarkan nilai nilai pancasila. 


\section{DAFTAR PUSTAKA}

Ali, A., \& Heryani, W. (2012). Menjelajahi Kajian Empiris Terhadap Hukum. Kencana.

Ali, Z. (2009). Hukum Pidana Islam. Sinar Grafika.

Amin, L. (2021). Bermain Game Online Sebagai Nafkah Keluarga Pada Masa Pandemi Covid-19 Perspfektif Hukum Islam [Skripsi, Universitas Islam Indonesia]. https://dspace.uii.ac.id/handle/123456789/34852

Bintang. (2021, October 21). Jual Chip Higgs Domino Rp70 ribu Per 1B, Pria di Rohul $\begin{array}{llll}\text { Ditangkap Polisi } & \text { [Web } & \text { Blog]. }\end{array}$ https://www.cakaplah.com/berita/baca/76627/2021/10/21/jual-chip-higgsdomino-rp70-ribu-per-1b-pria-di-rohul-ditangkap-polisi/

Fuady, M. (2007). Sosiologi Kontemporer, Interaksi Hukum, Kekuasaan Dan Masyarakat. Citra Aditya Bakti.

Harahap, N. K. (2021). Analisis Kelangkaan BBM Premium Di Padangsidimpuan Perspektif Hukum Positif Dan Hukum Ekonomi Syariah. Yurisprudentia: Jurnal Hukum Ekonomi, 7(1), 56-76. https://doi.org/10.24952/yurisprudentia.v7i1.3800

Jasmadi. (2004). Panduan Praktis Menggunakan Fasilitas Internet: Surfing, Email, SMS, Chating, E-Card, dan Download. CV. Andi Offset.

Nisrinafatin, N. (2020). Pengaruh Game Online Terhadap Motivasi Belajar Siswa. JURNAL EDUKASI NONFORMAL, 1(1), 135-142.

Qardhawi, Y. (1993). Halal dan Haram dalam Islam. PT. Bina Ilmu.

Qardhawi, Y. (2005). Fiqh Hiburan. Pustaka Al-Kausar.

Rajagukguk, T. P., \& Sofianto, K. (2020). Simulakra Hiperrealitas Dan Reproduksi Tanda Game Online-PUBG. Metahumaniora, 10(1), 118-136. https://doi.org/10.24198/metahumaniora.v10i1.22239

Ramadhani, P. (2021). Unsur Pidana dalam Game Online Higgs Domino yang chip/koin diperjualbelikan ditinjau dari perspektif Hukum Pidana Islam dan Hukum Positif. Juripol (Jurnal Institusi Politeknik Ganesha Medan), 4(2), 331-341.

Sugiyono. (2013). Metode Penelitian Kuantitatif, Kualitatif, dan RED. Alfabeta. 
Surbakti, K. (2017). Pengaruh Game Online terhadap Remaja. JURNAL CURERE, 1(1), Article 1. https://doi.org/10.36764/jc.v1i1.20

Tohet, M., \& Mauliza, S. (2021). Penanggulangan Kecanduan Game Online Melalui Pendidikan Karakter Regilius Pada Anak. Belajea: Jurnal Pendidikan Islam, 6(2), 147-164. https://doi.org/10.29240/belajea.v6i2.3434

W, I. R. (2021). Pemain dan Penjual Chip Higgs Domino Ditangkap, Barang Buktinya 87 B Seharga Rp5 Juta-Potensi Badung [Web Blog]. PotensiaBandung.Com. https://potensibadung.pikiran-rakyat.com/peristiwa/pr1622639034/pemain-dan-penjual-chip-higgs-domino-ditangkap-barangbuktinya-87-b-seharga-rp5-juta 